\title{
Peripartum Haemorrhage, Diagnosis and Therapy. Guideline of the DGGG, OEGGG and SGGG (S2k Level, AWMF Registry No. 015/063, March 2016)
}

\author{
Peripartale Blutungen, Diagnose und Therapie. \\ Leitlinie der DGGG, OEGGG und SGGG (S2k-Level, \\ AWMF-Registernummer 015/063, März 2016)
}

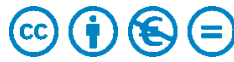

Authors

Dietmar Schlembach ${ }^{1}$, Hanns Helmer ${ }^{2}$, Wolfgang Henrich ${ }^{3}$, Christian von Heymann ${ }^{4}$, Franz Kainer ${ }^{5}$, Wolfgang Korte ${ }^{6}$, Maritta Kühnert ${ }^{7}$, Heiko Lier $^{8}$, Holger Maul ${ }^{9}$, Werner Rath ${ }^{10}$, Susanne Steppat ${ }^{11}$, Daniel Surbek ${ }^{12}$, Jürgen Wacker ${ }^{13}$

Affiliations

1 Klinik für Geburtsmedizin, Vivantes Klinikum Neukölln, Berlin, Germany

2 Universitätsklinik für Frauenheilkunde, Klinische Abteilung für Geburtshilfe und feto-maternale Medizin, Medizinische Universität Wien, Wien, Austria

3 Klinik für Geburtsmedizin, Charité - Universitätsmedizin Berlin, Berlin, Germany

4 Klinik für Anästhesie, Intensivmedizin und Schmerztherapie, Vivantes Klinikum im Friedrichshain, Berlin, Germany

5 Geburtshilfe und Pränatalmedizin, Klinik Hallerwiese, Nürnberg, Germany

6 Zentrum für Labormedizin, St. Gallen, Switzerland

7 Klinik für Frauenheilkunde und Geburtshilfe, Universitätsklinikum Gießen-Marburg, Marburg, Germany

8 Klinik für Anästhesie und operative Intensivmedizin, Universitätsklinik Köln, Köln, Germany

9 Geburtshilfe \& Pränatalmedizin, Asklepios Klinik Barmbek, Hamburg, Germany

10 Gynäkologie und Geburtshilfe, Universitätsklinikum RWTH Aachen, Aachen, Germany

11 Deutscher Hebammenverband, Karlsruhe, Germany

12 Universitätsklinik für Frauenheilkunde, Geburtshilfe und feto-maternale Medizin, Bern, Switzerland

13 Klinik für Gynäkologie und Geburtshilfe, Fürst-StirumKlinik Bruchsal, Bruchsal, Germany

Key words

peri-/postpartum haemorrhage, abnormally invasive placenta, uterine atony, surgical therapy, medical therapy, embolisation

\section{Schlüsselwörter}

peripartale Blutung, Plazentaimplantationsstörung, Uterusatonie, chirurgische Therapie, medikamentöse Therapie, Embolisation $\begin{array}{ll}\text { received } & 24.1 .2018 \\ \text { revised } & 8.2 .2018 \\ \text { accepted } & 26.2 .2018\end{array}$

Bibliography

DOI https://doi.org/10.1055/a-0582-0122

Geburtsh Frauenheilk 2018; 78: 382-399 @ Georg Thieme

Verlag KG Stuttgart · New York | ISSN 0016-5751

Correspondence

PD Dr. med. Dietmar Schlembach

Klinik für Geburtsmedizin, Vivantes Klinikum Neukölln,

Vivantes Netzwerk für Gesundheit GmbH

Rudower Straße 48, 12351 Berlin, Germany

drschlembach@gmx.net

$\circledast$

Deutsche Version unter:

https://doi.org/10.1055/a-0582-0122

\section{ABSTRACT}

Purpose This is an official interdisciplinary guideline, published and coordinated by the German Society of Gynaecology and Obstetrics (DGGG), the Austrian Society of Gynaecology and Obstetrics (OEGGG) and the Swiss Society of Gynaecology and Obstetrics (SGGG). The guideline was developed for use in German-speaking countries and is backed by the German Society of Anaesthesiology and Intensive Medicine (DGAI), the Society of Thrombosis and Haemostasis Research (GTH) and the German Association of Midwives. The aim is to provide a consensus-based overview of the diagnosis and management of peripartum bleeding obtained from an evaluation of the relevant literature.

Methods This S2k guideline was developed from the structured consensus of representative members of the various 
professional associations and professions commissioned by the Guideline Commission of the DGGG.

Recommendations The guideline encompasses recommendations on definitions, risk stratification, prevention and management.

\section{ZUSAMMENFASSUNG}

Ziel Erstellung einer offiziellen interdisziplinären Leitlinie, publiziert und koordiniert von der Deutschen Gesellschaft für Gynäkologie und Geburtshilfe (DGGG), der Österreichischen Gesellschaft für Gynäkologie und Geburtshilfe (OEGGG) und der Schweizerischen Gesellschaft für Gynäkologie und Geburtshilfe (SGGG). Die Leitlinie wurde für den deutschsprachi- gen Raum entwickelt und wird von der Deutschen Gesellschaft für Anästhesiologie und Intensivmedizin (DGAI), der Gesellschaft für Thrombose- und Hämostaseforschung (GTH) und dem Deutschen Hebammenverband mitgetragen. Das Ziel dieser Leitlinie ist es, durch die Evaluation der relevanten Literatur einen konsensbasierten Überblick über die Diagnostik und das Management der peripartalen Blutung zu geben. Methoden Diese S2k-Leitlinie wurde durch einen strukturierten Konsens von repräsentativen Mitgliedern verschiedener Fachgesellschaften und Professionen im Auftrag der Leitlinienkommission der DGGG entwickelt.

Empfehlungen Es werden Empfehlungen zur Definition, Risikostratifizierung, Prävention und Management gegeben.

\section{Guideline Information}

\section{Guidelines programme of the DGGG, OEGGG and SGGG}

Information on the guidelines programme is available at the end of the guideline.

\section{Citation format}

Peripartum haemorrhage, diagnosis and therapy. Guideline of the DGGG, OEGGG and SGGG (S2k Level, AWMF Registry No. 015/ 063, March 2016). Geburtsh Frauenheilk 2018; 78: 382-399

\section{Guideline documents}

The complete long version (in German), a PDF slideshow for PowerPoint presentations and a summary of the conflicts of interest of all the authors is available on the AWMF homepage under: http://www.awmf.org/leitlinien/detail/II/015-063.html

\section{Guideline authors}

The following professional and scientific societies/working groups/organisations/associations have stated their interest in contributing to the compilation of the guideline text and participating in the consensus conference and nominated representatives to attend the consensus conference ( $\triangleright$ Table $\mathbf{1}$ ).

- Table 1 Authors and representativity of the guideline group: participation of the target user group.

\begin{tabular}{l|l}
$\begin{array}{l}\text { Author } \\
\text { Mandate holder }\end{array}$ & DGGG working group/AWMF/non-AWMF professional societies/organisations/associations \\
\hline \begin{tabular}{l} 
Lead author and/or coordinating author: \\
\hline PD Dr. med. Dietmar Schlembach
\end{tabular} & $\begin{array}{l}\text { German Society of Gynaecology and Obstetrics (Deutsche Gesellschaft für Gynäkologie und Geburtshilfe e. V. } \\
\text { [DGGG]) }\end{array}$ \\
\hline Other lead authors: & $\begin{array}{l}\text { Austrian Society of Gynaecology and Obstetrics (Österreichische Gesellschaft für Gynäkologie und Geburtshilfe } \\
\text { [OEGGG]) }\end{array}$ \\
\hline Prof. Dr. med. Hanns Helmer & German Society of Gynaecology and Obstetrics (DGGG) \\
\hline Prof. Dr. med. Wolfgang Henrich & $\begin{array}{l}\text { German Society of Anaesthesiology and Intensive Medicine (Deutsche Gesellschaft für Anästhesiologie } \\
\text { und Intensivmedizin e.V. [DGAl]) }\end{array}$ \\
\hline Prof. Dr. med. Christian von Heymann & German Society of Gynaecology and Obstetrics (DGGG) \\
\hline Prof. Dr. med. Franz Kainer & $\begin{array}{l}\text { Society of Thrombosis and Haemostasis Research (Gesellschaft für Thrombose- und Hämostaseforschung e. V. } \\
\text { [GTH]) }\end{array}$ \\
\hline Prof. Dr. med. Wolfgang Korte & German Society of Gynaecology and Obstetrics (DGGG) \\
\hline Prof. Dr. med. Maritta Kühnert & German Society of Anaesthesiology and Intensive Medicine (DGAl) \\
\hline Dr. med. Heiko Lier & Deutsche Society of Gynaecology and Obstetrics (DGGG) \\
\hline PD Dr. med. Holger Maul & German Society of Gynaecology and Obstetrics (DGGG) \\
\hline Prof. Dr. med. Werner Rath & German Society of Midwives (Deutscher Hebammenverband e. V.) \\
\hline Susanne Steppat & $\begin{array}{l}\text { Swiss Society of Gynaecology and Obstetrics (Schweizerische Gesellschaft für Gynäkologie und Geburtshilfe e.V. } \\
{[\text { SGGG]) }}\end{array}$ \\
\hline Prof. Dr. med. Daniel Surbek & Germany Society of Gynaecology and Obstetrics (DGGG) \\
\hline Prof. Dr. med. Jürgen Wacker & \\
\hline
\end{tabular}




\section{Abbreviations}

$\begin{array}{ll}\text { AAGBI } & \text { Association of Anaesthetists of Great Britain } \\ \text { AFE } & \begin{array}{l}\text { and Ireland } \\ \text { amniotic fluid embolism }\end{array} \\ \text { AMSTL } & \text { active management of third stage of labour } \\ \text { aPTT } & \text { activated partial thromboplastin time } \\ \text { AT/AT III } & \text { antithrombin/antithrombin III } \\ \text { BGA } & \text { blood gas analysis } \\ \text { BMI } & \text { body mass index } \\ \text { BL } & \text { blood loss } \\ \text { BW } & \text { body weight } \\ \text { CMACE } & \text { Centre for Maternal and Child Enquiries } \\ \text { DDAVP } & \text { desmopressin } \\ \text { DIC } & \text { disseminated intravascular coagulation } \\ \text { ESA } & \text { European Society of Anaesthesiology } \\ \text { FFP } & \text { fresh frozen plasma } \\ \text { Hb } & \text { haemoglobin } \\ \text { HR } & \text { heart rate } \\ \text { Hct } & \text { haematocrit } \\ \text { IM } & \text { intramuscular } \\ \text { INR } & \text { international normalized ratio } \\ \text { IU } & \text { international unit } \\ \text { IUFD } & \text { intrauterine fetal death } \\ \text { IV } & \text { intravenous } \\ \text { MAP } & \text { mean arterial pressure } \\ \text { MRI } & \text { magnetic resonance imaging } \\ \text { NICE } & \text { National Institute for Health and Care Excellence } \\ \text { OAA } & \text { Obstetric Anaesthetists Association } \\ \text { OR } & \text { odds ratio } \\ \text { PCC } & \text { prothrombin complex concentrate } \\ \text { POC } & \text { point of care } \\ \text { PPH } & \text { postpartum haemorrhage } \\ \text { rFVIla } & \text { recombinant factor VIIa } \\ \text { RBC } & \text { red blood cell concentrate } \\ \text { ROTEM } & \text { rotational thromboelastometry } \\ \text { RR } & \text { Sys } / \text { RR dia } \\ \text { SR systolic/RR diastolic } \\ \text { TEG } & \text { status post } \\ \text { US } & \text { thromboelastography } \\ \text { VET } & \text { vitrasound } \\ \text { WHO } & \text { World Health Organisation } \\ \end{array}$

\section{Guideline Application}

\section{Purpose and objectives}

This aim of this guideline is to create an interdisciplinary (including anaesthesiologists and intensive care physicians, obstetricians, midwives, puerperal care nursing staff) management and treatment algorithm for the management of peripartum haemorrhage (diagnosis, risk selection, therapy).
The guideline was compiled to improve the knowledge of all persons involved in the care of pregnant women and women in childbed who experience or have an increased risk of haemorrhage.

The aim was to improve the care of affected patients and reduce problems in the management of $\mathrm{PPH}$.

\section{Targeted areas of patient care}

- Outpatient care

- Primary/specialised care

- Inpatient care

\section{Target user groups/target audience}

This guideline is aimed at the following groups of people:

- gynaecologists/obstetricians in private practice (non-hospital based)

- hospital-based gynaecologists/obstetricians

- anaesthesiologists and intensive care physicians

- haemostasis specialists and lab clinicians

- interventional radiologists

- midwives

- nursing staff (surgery, anaesthesiology, intensive care unit, obstetrics/postpartum care)

\section{Adoption of the guideline and period of validity}

The validity of this guideline was confirmed in September 2015 by the respective boards/representatives of the participating professional societies/working groups/organisations/associations, by the board of the DGGG and the DGGG Guideline Commission and by the SGGG and the OEGGG, which constitutes approval of the entire contents of the guideline. This guideline is valid from May 1, 2016 through to March 31, 2019. Because of the contents of this guideline, the above-mentioned period of validity is only an estimate. The guideline can be updated earlier if urgently required. Should the guideline continue to reflect the current level of scientific knowledge, then the guideline's period of validity can be extended.

\section{Methodology}

\section{Basic principles}

The methodology used to compile this guideline is determined by the class assigned to the guideline. The AWMF Guidance Manual (version 1.0) has set out the respective rules and requirements. Guidelines are differentiated into lowest (S1), intermediate (S2) and highest (S3) class. The lowest class consists of a set of recommendations for action compiled by a non-representative group of experts. In 2004 the S2 class was divided into two subclasses: a systematic evidence-based (S2e) subclass and a structural consensus-based subclass ( $52 \mathrm{k}$ ). The highest $\mathrm{S3}$ class combines both approaches.

This guideline is classified as: $\mathbf{S 2 k}$ 


\section{Grading of recommendations}

The grading of evidence and the grading of recommendations was not envisaged for $\mathbf{2} \mathrm{k}$ class guidelines. Individual statements and recommendations are differentiated by syntax, not by symbols ( $\triangleright$ Table 2 ).

- Table 2 Grading of recommendations.

\begin{tabular}{|l|l|}
\hline Description of grade of recommendation & Syntax \\
\hline Strong recommendation, highly binding & must/must not \\
\hline Recommendation, moderately binding & should/should not \\
\hline Open recommendation, not binding & may/may not \\
\hline
\end{tabular}

The above classification of recommendations reflects the evaluated evidence and the clinical relevance of the studies on which the recommendations are based and various measures/factors which did not appear in the grading of evidence, such as the choice of patient population, intention-to-treat or per-protocoloutcome analyses, medical or ethical behaviour towards patients, country-specific application, etc.

\section{Statements}

Expert statements included in this guideline which are not recommendations for action but simple statements of fact are referred to as statements. It is not possible to provide a level of evidence for these statements.

\section{Achieving consensus and level of consensus}

During structured consensus-based decision-making (S2k/S3 level), the authorised representatives present at the respective session vote on draft Statements and Recommendations. Discussions during the session may lead to significant changes in the wording of Statements and Recommendations. At the end of the session, the extent of agreement (level of consensus) is determined based on the number of participants ( $\triangleright$ Table 3 ).

- Table 3 Classification of extent of agreement in consensus decisionmaking.

\begin{tabular}{|l|l|l|}
\hline Symbol & Level of consensus & $\begin{array}{l}\text { Extent of agreement } \\
\text { in percent }\end{array}$ \\
\hline+++ & Strong consensus & $>95 \%$ of participants agree \\
\hline++ & Consensus & $>75-95 \%$ of participants agree \\
\hline+ & Majority agreement & $>50-75 \%$ of participants agree \\
\hline- & No consensus & $<50 \%$ of participants agree \\
\hline
\end{tabular}

\section{Expert consensus}

As the name implies, this refers to consensus decisions taken with regard to specific Recommendations/Statements without a previous systematic search of the literature (S2k) or when evidence is lacking (S2e/S3). The term "Expert Consensus" (EC) used here is synonymous with the terms "Good Clinical Practice" (GCP) and "Clinical Consensus Point" (CCP) used in other guidelines. The level of recommendation is graded as previously described in the Chapter Grading of recommendations but only semantically ("must"|"must not" or "should"|"should not" or "may"|"may not") and without using symbols.

\section{Guideline}

\section{Introduction}

The incidence of postpartum haemorrhage (PPH) is continually increasing [1-5], mostly because of the increase in uterine atony and disorders of placental implantation and increased rates of surgical vaginal delivery and Caesarean sections and the consequent increase in primary blood loss and, in the case of Caesarean section, the increased PPH rates in subsequent pregnancies [2,611].

In the western world, life-threatening postpartum haemorrhage occurs in approximately 2 of 1000 births and severe maternal morbidity occurs in around 3 of 1000 births [12-22]. PPH is

\begin{tabular}{|c|c|}
\hline \multirow{6}{*}{$\begin{array}{l}\text { Tone } \\
\text { (uterine } \\
\text { atony) }\end{array}$} & $\begin{array}{l}\text { Uterine distension } \\
\text { (multiparity, polyhydramnios, fetal macrosomia) }\end{array}$ \\
\hline & Tocolytics \\
\hline & Precipitate labour or prolonged labour \\
\hline & (Prolonged) oxytocin augmentation \\
\hline & Chorioamnionitis \\
\hline & Uterine fibroids \\
\hline \multirow{3}{*}{$\begin{array}{l}\text { Tissue } \\
\text { (placenta) }\end{array}$} & Retained placenta \\
\hline & $\begin{array}{l}\text { Abnormally invasive placenta } \\
\text { (morbidly adherent placenta, placenta accreta/ } \\
\text { increta/percreta) }\end{array}$ \\
\hline & Placental remnants \\
\hline \multirow[t]{5}{*}{ Trauma } & Vulvovaginal injury \\
\hline & Cervical tear \\
\hline & Episiotomy/perineal tear \\
\hline & Uterine rupture \\
\hline & Uterine inversion \\
\hline \multirow{4}{*}{$\begin{array}{l}\text { Thrombin } \\
\text { (coagulo- } \\
\text { pathy) }\end{array}$} & Pregnancy-induced: \\
\hline & $\begin{array}{l}\text { Thrombocytopenia (HELLP syndrome, disseminated } \\
\text { intravascular coagulation [DIC]) (e.g. in pre-eclampsia, } \\
\text { intrauterine fetal death [IUFD], placental abruption, } \\
\text { amniotic fluid embolism) }\end{array}$ \\
\hline & Other: \\
\hline & $\begin{array}{l}\text { von Willebrand disease, plasmatic coagulopathies, } \\
\text { thrombopathy, coagulation factor deficiencies } \\
\text { (loss, consumption, dilution) }\end{array}$ \\
\hline
\end{tabular}


the cause of approximately $30 \%$ of all maternal deaths in the Third World and $13 \%$ of maternal deaths in industrialised countries [21].

The majority of maternal deaths from PPH could be avoided; major substandard care was present in $60-80 \%$ of all cases [ 1 , $20,21,23-25]$. What is especially alarming is that a visual estimation of blood loss during delivery results in the extent of bleeding being underestimated by $30-50 \%$ [26-29].

In Britain and America, the causes of PPH have been summarized as the "4 Ts". (Combinations of these causes are the rule.) ( $\triangleright$ Table 4).

The main risk management problems in the management of $\mathrm{PPH}$ are $[1,24,33,34]$ :

- Delayed diagnosis and/or therapy due to underestimation of the actual amount of blood lost

- Delayed provision of blood or coagulation products

- Lack of or failure to follow simple instructions

- Lack of adequate training or advanced training

- Poor communication within the interdisciplinary team

- Deficits in the organisational structure

- Delay in initiating treatment standards

\section{Definitions}

\begin{tabular}{l}
\hline \multicolumn{2}{|c|}{ Consensus-based Recommendation 2.E1 } \\
\hline Expert consensus \\
\hline The following definition of PPH is proposed (for German-speaking areas): \\
- Blood loss of $\geq 500 \mathrm{ml}$ following vaginal delivery \\
- Blood loss of $\geq 1000 \mathrm{ml}$ following Caesarean section
\end{tabular}

\section{Risk Stratification and Prevention}

A complete and detailed patient history, ultrasound examination during antenatal appointments, assessment of the patient's risk of bleeding, presentation to the maternity hospital, and preparations for increased blood loss could reduce patients' risk of PPH [35].

\section{Consensus-based Recommendation 3.E2
$\begin{aligned} & \text { Expert consensus } \\ & \text { Level of consensus +++ }\end{aligned}$
Location and structure of the placenta must be documented during ultra-
sound examination in the 2nd trimester. If necessary, patients with low-
lying placenta should undergo an additional ultrasound scan to screen for
vasa praevia and the findings should be documented [36].}

\begin{tabular}{|c|c|}
\hline \multicolumn{2}{|c|}{ Consensus-based Recommendation 3.E3 } \\
\hline Expert consensus & Level of consensus +++ \\
\hline \multicolumn{2}{|c|}{$\begin{array}{l}\text { An implantation disorder should be considered in women with a high-risk } \\
\text { history (previous operations) or findings (placenta praevia) which indicate } \\
\text { high risk. }\end{array}$} \\
\hline
\end{tabular}

3.1 Risk stratification and risk factors which facilitate peripartum/postpartum haemorrhage ( $\bullet$ Table 5 )

- Table 5 Risk factors for PPH [16, 23, 37 - 39].

\begin{tabular}{|c|c|c|}
\hline \multirow[b]{2}{*}{ Blood loss } & \multicolumn{2}{|c|}{ Odds ratio or range } \\
\hline & $>500 \mathrm{ml}$ & $>1000 \mathrm{ml}$ \\
\hline \multicolumn{3}{|l|}{ Sociodemographic risk factors } \\
\hline - obesity (BMI > 35) & 1.6 & \\
\hline - maternal age ( $\geq 30$ years) & $1.3-1.4$ & 1.5 \\
\hline \multicolumn{3}{|l|}{ Obstetric risk factors } \\
\hline - placenta praevia & $4-13.1$ & 15.9 \\
\hline - premature placental separation & $2.9-12.6$ & 2.6 \\
\hline - retained placenta & $4.1-7.8$ & $11.7-16.0$ \\
\hline - prolonged expulsion of the placenta & 7.6 & \\
\hline - pre-eclampsia & 5.0 & \\
\hline - grand multiparity & $2.3-4.5$ & 2.6 \\
\hline - s/pPPH & $3.0-3.6$ & \\
\hline - fetal macrosomia & $1.9-2.4$ & \\
\hline - HELLP syndrome & 1.9 & \\
\hline - Polyhydramnios & 1.9 & \\
\hline - (prolonged) oxytocin augmentation & 1.8 & \\
\hline - labour induction & $1.3-2$ & $2.1-2.4$ \\
\hline - protracted labour & $1.1-2$ & \\
\hline \multicolumn{3}{|l|}{ Surgical risk factors } \\
\hline - emergency Caesarean section & 3.6 & \\
\hline - elective Caesarean section & 2.5 & \\
\hline - operative vaginal delivery & $1.8-1.9$ & \\
\hline - episiotomy & $1.7-2.21$ & 2.07 \\
\hline - perineal tear & 1.7 & 2.5 \\
\hline \multicolumn{3}{|l|}{ Other risk factors } \\
\hline - antepartum haemorrhage & 3.8 & \\
\hline - von Willebrand disease & 3.3 & \\
\hline - anaemia (<9 g/dl) & 2.2 & \\
\hline - fever during delivery & 2 & \\
\hline
\end{tabular}

Other risk factors include precipitous birth, high maternal parity, fibroids and uterine malformations [39].

Caution: The majority of patients who develop PPH do not have identifiable risk factors [39].

\subsection{Sonographic risk stratification (placentation disorders)}

\section{Consensus-based Recommendation 3.E4}

\section{Expert consensus}

Level of consensus +++

Patients with suspected abnormally invasive placenta must present early to a suitable maternity hospital where they must be treated by a multidisciplinary team ("by the best team at an optimal point in time") $[20,40]$. 
The diagnostic value of MRI has not yet been convincingly demonstrated in these cases $[41,42]$, but MRI examination could provide additional information when findings are ambiguous $[42,43]$.

\subsection{Prevention}

\subsubsection{Active management of third stage of labour}

\subsubsection{Active management after vaginal delivery}

\begin{tabular}{l} 
Consensus-based Recommendation 3.E5 \\
$\begin{array}{l}\text { Expert consensus } \\
\text { After the infant has been born and commenced breathing, oxytocin (Syn- } \\
\text { tocinon }{ }^{\circledR} 3-5 \text { IU slow IV infusion) must be administered for PPH prevention } \\
{[44] .}\end{array}$ \\
\hline
\end{tabular}

\section{Consensus-based Recommendation 3.E6}

Expert consensus

Level of consensus ++

Immediate clamping of the umbilical cord at birth and controlled cord traction have no impact on reducing postpartum haemorrhage and should not be carried out.

\subsubsection{Prevention of PPH during Caesarean section}

\section{Consensus-based Recommendation 3.E7}

Expert consensus

Level of consensus +++

$\mathrm{PPH}$ prophylaxis must be administered as in vaginal delivery.

Prophylaxis can consist of administering either oxytocin (Syntocinon ${ }^{\circledR}$ 3-5 IU by short infusion [or slow IV infusion]) or carbetocin $\left(\right.$ Pabal $^{\circledR} 100 \mu \mathrm{g}$ ) by short infusion or slow IV infusion.

\subsubsection{If risk factors are present}

Consensus-based Recommendation 3.E8

Expert consensus Level of consensus +++

If risk factors are present, the following measures must be taken:

- Adequate venous access for every woman in labour, adequate intravenous access in case of complications of bleeding

- Uterotonics must be available (oxytocin, e.g. Syntocinon ${ }^{\circledR}$ ), prostaglandins (e.g. sulprostone: Nalador ${ }^{\circledR}$ ), misoprostol (Cytotec ${ }^{\circledR}$, off-label use)

- Check logistics:

- Check availability of emergency laboratory tests (complete blood count, blood gas analysis [BGA], aPTT, prothrombin time [PT] or INR, antithrombin [AT], fibrinogen, possibly thromboelastography or thromboelastometry [ROTEM])

- Obstetrician and anaesthesiologist must be on site, experienced obstetrician and experienced anaesthesiologist on call

- Check availability of blood products: cross-matching, ordering of packed red blood cells, fresh frozen plasma and platelets

- Check availability of haemostatic agents (tranexamic acid [Cyclokapron $^{\circledR}$ ], fibrinogen [Haemocomplettan ${ }^{\circledR}$ ], factor XIII [Fibrogammin ${ }^{\circledR}$ ], recombinant activated factor VII a [rFVIla, NovoSeven ${ }^{\circledR}$, off-label use]).

\section{Management of PPH}

\begin{tabular}{|c|c|}
\hline \multicolumn{2}{|c|}{ Consensus-based Statement 4.S1 } \\
\hline Expert consensus & Strength of consensus +++ \\
\hline \multicolumn{2}{|c|}{$\begin{array}{l}\text { Alongside general interventions (such as stabilising the patient's haemo- } \\
\text { dynamic status), causal treatment of PPH includes medical therapy and/or } \\
\text { surgical procedures that must be performed quickly, in a coordianted and } \\
\text { often simultaneous manner [ } 45-47] \text {. }\end{array}$} \\
\hline
\end{tabular}

\subsection{Procedures}

- Measure blood loss! (Caution: blood loss in bandages, etc.)

- Rapid diagnosis of the cause of bleeding (4 T's):

- Estimation of uterine tone

- Check whether placenta is complete (ultrasound, manual or instrumental examination)

- Exclude vulvovaginal trauma by speculum examination

- Administer uterotonics (in case of atony) and tranexamic acid to treat critical blood loss

- Uterine compression

- Call in anaesthesiologist (multidisciplinary team) at an early stage

- Drug therapy and/or surgical procedures, depending on the cause of bleeding

- Control vital signs, consider timely invasive monitoring

- Initial volume substitution to maintain normovolaemia: cristalloids, in exceptional cases (e.g. acute haemorrhage and haemodynamic instability) colloidal solutions [48]

- Cross-matching of blood, emergency laboratory tests (incl. full blood count, coagulation)

- Order packed red blood cells and fresh frozen plasma, provide blood products if required (delivery room, operating theatre)

- Coagulation factors, especially fibrinogen

- Other haemostatic agents (e.g. desmopressin), factor XIII or rFVIla if necessary

- Intensive monitoring of patient during hospital stay, consider invasive monitoring

- Timely surgical intervention when conservative measures fail (see below for appropriate procedures)

\section{Measuring blood loss}

One of the cardinal problems which occur not only when defining but primarily when diagnosing and treating PPH is that the extent of postpartum blood loss is rarely measured and is known to be

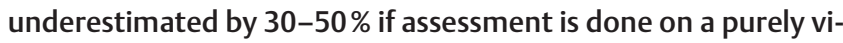
sual basis $[35,49]$.

\begin{tabular}{l}
\hline \multicolumn{1}{|c|}{ Consensus-based Recommendation 4.E9 } \\
\hline \multicolumn{1}{|c|}{ Expert consensus } \\
\hline $\begin{array}{l}\text { Collecting all blood-soaked pads, bedding, linens and significant coagulum } \\
\text { is strongly recommended. }\end{array}$ \\
\hline
\end{tabular}


$5 \quad$ General (Emergency) Measures and Diagnosis to Determine Causes of PPH

5.1 Atony

- Diagnosis: increased fundal height; soft slack uterus; usually intermittent heavy bleeding.

- Void the bladder!

- Mechanical procedures: uterine massage (endogenous prostaglandin formation), bimanual uterine compression (e.g. Hamilton's manoeuvre)

- Exclude vulvovaginal trauma (by speculum examination and abdominal US if necessary)

- Exclude retained placenta (examine the placenta to ensure it is complete, sonography)

\begin{tabular}{l}
\multicolumn{2}{c}{ Consensus-based Recommendation $\mathbf{5 . E 1 0}$} \\
\hline \multicolumn{1}{c|}{ Expert consensus } \\
\hline Therapy: \\
After vaginal delivery \\
- uterotonics, tranexamic acid if required \\
- careful curettage in the delivery room or operating theatre if retained \\
placenta is suspected \\
- uterine tamponade if required \\
" other surgical procedures \\
- consider embolisation \\
After caesarean section \\
- uterotonics, tranexamic acid if required \\
- surgical procedures
\end{tabular}

\subsection{Implantation disorders}

The management of abnormally invasive placenta depends on the time of diagnosis and type of delivery.

\section{Approach for antenatal diagnosis}

If an advanced implantation disorder (placenta increta, percreta) is diagnosed in the antenatal period, delivery must always be by Caesarean section.

- Extensive findings: Caesarean section with hysterectomy; alternatively, consider expectant management (e.g. delayed delivery of placenta)

- Focal findings: partial resection of the uterine wall

- If necessary carry out interventional radiology with prophylactic occlusion of the internal iliac arteries $[50,51]$

\section{Approach for intrapartum diagnosis}

- Vaginal delivery:

- If the placenta fails to separate and bleeding is present: carry out manual separation of the placenta followed by curettage with intraoperative ultrasound monitoring, if required [52]

- If severe bleeding from the placental bed persists: carry out surgical therapy, alternatively embolisation of the uterine arteries

- Caesarean section:

- Do not manipulate the placenta or attempt to separate it manually

- Perform Caesarean section with hysterectomy or alternatively consider expectant management (e.g. delayed delivery of placenta)

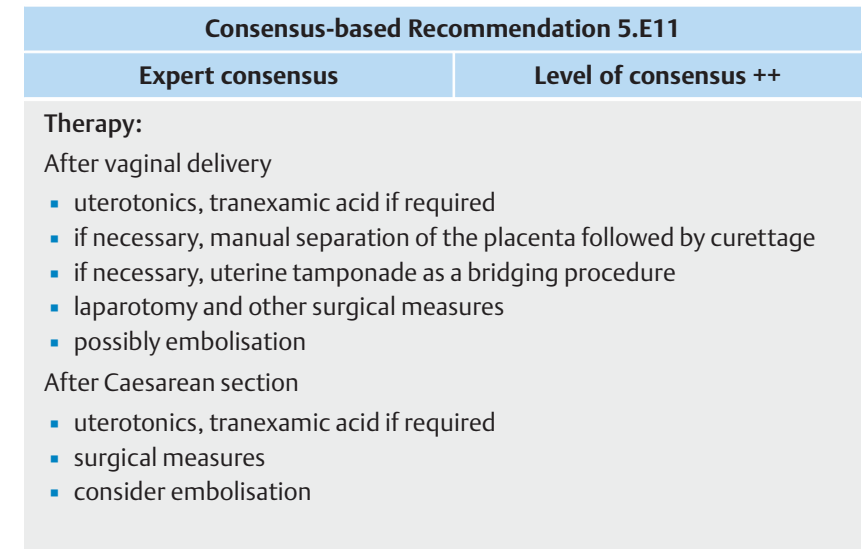

\subsection{Uterine inversion}

\begin{tabular}{l} 
Consensus-based Recommendation $5 . E 12$ \\
\hline Expert consensus \\
Therapy: \\
The goal is the reposition of the uterus and treatment of the symptoms \\
of haemorrhagic shock. The following procedures must be carried out \\
immediately after making the diagnosis in the order stated below: \\
- Stop administration of any uterotonic drug \\
- Call in experienced obstetrician and anaesthesiologist \\
- Ensure adequate intravenous access, volume substitution \\
- Make no attempt to remove the placenta (higher blood loss); the \\
placenta must, where possible (placenta accreta), only be removed \\
after repositioning [ 53,54$]$ \\
- Attempt to reposition the fundus (Johnson's manoeuvre) \\
- If attempts at repositioning are unsuccessful, administer uterine relax- \\
ants (e.g. nitroglycerin 50 pg IV, betamimetics) and repeat the attempt \\
to reposition the uterus with johnson's manoeuvre \\
- If repositioning attempts continue to be unsuccessful $\rightarrow$ perform lapa- \\
rotomy and Huntington's procedure, simultaneously with johnson's \\
manoeuvre if necessary; if attempts are still unsuccessful, perform the \\
Haultain procedure \\
- Administer uterotonics (e.g. oxytocin) after successful repositioning \\
- Provide antibiotic protection (e.g. cephalosporin or clindamycin)
\end{tabular}

\section{$6 \quad$ Medication and Surgical Measures to Treat PPH}

\section{$6.1 \quad$ Uterotonics}

\subsubsection{Oxytocin (Syntocinon ${ }^{\circledR}$ ) IV (IM if necessary)}




\subsubsection{Carbetocin $\left(\mathrm{Pabal}^{\circledR}\right)$}

The use of carbetocin to treat PPH is currently not yet been sufficiently investigated. The use of carbetocin to treat PPH has been reported in individual cases.

\subsubsection{Methylergometrine (Methergin ${ }^{\circledR}$ )}

Consensus-based Recommendation 6.E14

Expert consensus

Level of consensus +++

Given the range of serious side effects and the fact that better alternatives are available, the utmost caution is advised when administering methylergometrine to manage postpartum haemorrhage.

Consensus-based Recommendation 6.E15

Expert consensus

Level of consensus ++

Methylergometrine should not be administered as an intravenous bolus.

\subsubsection{Prostaglandins}

\section{Consensus-based Recommendation 6.E16}

Expert consensus

Level of consensus +++

If first-line uterotonics are not effective and patients do not respond to firstline uterotonics, prostaglandins must be administered immediately [56].

\section{Consensus-based Recommendation 6.E17}

Expert consensus

Level of consensus +++

Oxytocin receptor agonists and prostaglandins must not be administered simultaneously.

\begin{tabular}{l} 
Consensus-based Statement 6.52 \\
\hline \multicolumn{1}{c}{ Expert consensus } \\
Note: \\
Postpartum uterine atony and uterine haemorrhage are life-threatening \\
pathologies and an urgent indication for the administration of prostaglan- \\
din derivatives if no other alternatives are available or oxytocin is not effec- \\
tive, until patients can receive obstetric/gynaecological treatment. In this \\
situation the side effects and contraindications must be carefully consid- \\
ered (benefits and drawbacks weighed up). Close haemodynamic moni- \\
toring is necessary when prostaglandin derivatives are administered.
\end{tabular}

\subsubsection{Sulprostone $\left(\right.$ Nalador $^{\circledR}$ ) \\ Dosage:}

- 1 vial = $500 \mu \mathrm{g}$ in $500 \mathrm{ml}$ solution administered via an infusion pump

- Initial dose: $100 \mathrm{ml} / \mathrm{h}$, up to a maximum of $500 \mathrm{ml} / \mathrm{h}$ if required

- Maintenance dose: $100 \mathrm{ml} / \mathrm{h}$

- Maximum dose $1000 \mu \mathrm{g} / 10$ hours (2 vials)

- Maximum daily dose $1500 \mu \mathrm{g}$ (3 vials)

\subsubsection{Misoprostol (Cytotec ${ }^{\circledR}$ )}

Dosage: $800-1000 \mu \mathrm{g}$ misoprostol administered rectally or $600 \mu \mathrm{g}$ administered orally [57-60].

A Cochrane meta-analysis showed that oxytocin infusion was more effective as a first-line therapy than the administration of misoprostol and additionally had fewer side effects. When used after prophylactic uterotonics, misoprostol and oxytocin were equally effective [61].

\begin{tabular}{l} 
Consensus-based Statement 6.53 \\
\hline \multicolumn{1}{c|}{ Expert consensus } \\
\hline Note: \\
Because of its delayed onset of action and the availability of better and \\
approved alternatives, misoprostol is not suitable to treat persistent PPH. \\
The use of misoprostol to treat moderately persistent PPH after the admin- \\
istration of oxytocin may be considered (off-label use!). However, the cur- \\
rent data is still insufficient to make a final recommendation.
\end{tabular}

\begin{tabular}{|c|c|}
\hline \multicolumn{2}{|c|}{ Consensus-based Statement 6.54} \\
\hline Expert consensus & Level of consensus +++ \\
\hline \multicolumn{2}{|l|}{ Note: } \\
\hline \multicolumn{2}{|c|}{$\begin{array}{l}\text { Postpartum uterine atony and uterine haemorrhage are life-threatening } \\
\text { pathologies and the administration of misoprostol is urgently indicated if } \\
\text { no other alternatives are available, until patients can receive obstetric/ } \\
\text { gynaecological treatment. In this context the side effects and contraindi- } \\
\text { cations must be carefully considered (benefits and drawbacks weighed up). } \\
\text { Close haemodynamic monitoring is essential when misoprostol is adminis- } \\
\text { tered. }\end{array}$} \\
\hline
\end{tabular}

\subsubsection{Intrauterine application of prostaglandins}

Consensus-based Statement 6.S5
$\begin{aligned} & \text { Expert consensus } \\ & \text { Level of consensus +++ }\end{aligned}$
The intramyometrial application of sulprostone (e.g. to the uterine fundus
in cases with caesarean section) is contra-indicated [56].

\section{$7 \quad$ Uterine Tamponade}

The objective of uterine cavity tamponade is twofold: to treat PPH (i.e., to achieve definitive haemostasis) and as a "bridging" measure (i.e., to achieve temporary haemostasis and haemodynamic stabilisation and allow other measures [surgical or interventional radiology] to be put in place) [62-64]. In addition to other second-line treatment strategies, uterine tamponade can significantly reduce the rate of emergency hysterectomies $[65,66]$.

In addition to tamponade strips, there are a number of different balloon tamponade systems available for uterine tamponade; their efficacy has been described in various publications and their use has the advantage of allowing the early detection of persistent bleeding $[64,67-73]$. 


\section{Consensus-based Recommendation 7.E18}

\section{Expert consensus} Level of consensus ++

- Parallel administration of uterotonics

- Vaginal examination/ultrasound (to exclude trauma, retained placenta, clot evacuation)

- Bladder catheter

- Use a liquid ( $0.9 \%$ saline, body temperature if possible) to fill the balloon tamponade - NOT air

- Additional vaginal tamponade

- Intensive monitoring, antibiotic prophylaxis

- Can be left in utero for up to 24 hours

There has been a recent report on the use of a special gauze $\left(\right.$ Celox $\left.^{\circledR}\right)$ coated with a haemostatic agent (chitosan), originally developed for emergency treatment and military combat medicine, to successfully manage PPH [74].

\section{Consensus-based Recommendation 7.E19}

\section{Expert consensus}

Level of consensus ++

Uterine tamponade - in whatever form - does not preclude other necessary therapeutic options, such as compression sutures $[64,75]$; the use of compression sutures is strongly recommended, particularly to treat atony [75-78].

\section{8}

$$
\begin{aligned}
& \text { Surgical Measures (Compression, Devascular- } \\
& \text { isation, Hysterectomy) and Embolisation }
\end{aligned}
$$

\subsection{Bridging procedures}

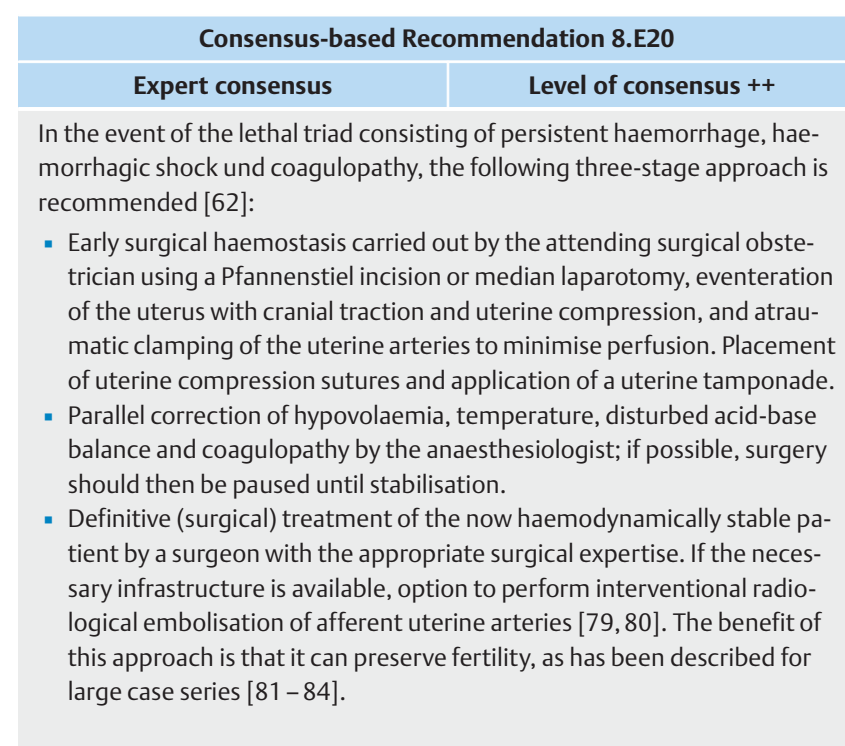

\subsection{Uterine compression sutures}

The aim of these sutures is to compress the uterus, reduce the placental adhesion area and tamponade the bleeding site. This approach is indicated for uterine bleeding after vaginal delivery or following Caesarean section. At present it is not possible to say anything about the optimal efficacy of specific types of sutures. All of the employed methods had high success rates in terms of preventing hysterectomy which would otherwise have been necessary. The choice of the appropriate suture method depends on the indication (atony, bleeding from the placental bed, diffuse bleeding) [85].

\begin{tabular}{|l|}
\hline \multicolumn{2}{|c|}{ Consensus-based Recommendation 8.E21 } \\
\hline \multicolumn{1}{|c|}{ Expert consensus } \\
\hline $\begin{array}{l}\text { Suitable suture materials (large needles, long suture threads) must be kept } \\
\text { in readiness in the operating theatre. }\end{array}$
\end{tabular}

\subsection{Vascular ligatures}

In addition to simple ligature of the uterine artery [86] stepwise uterine devascularisation can also be used for haemostasis. The technique consists of 5 consecutive steps to ligate the ascending and descending branches of the uterine arteries and the ovarian arterial collaterals $[87,88]$.

\begin{tabular}{|l|l|}
\hline \multicolumn{2}{|c|}{ Consensus-based Recommendation 8. E22 } \\
\hline Expert consensus & Level of consensus +++ \\
\hline $\begin{array}{l}\text { Ligature of the internal iliac artery must only be carried out as a last resort } \\
\text { and only by a surgeon with extensive experience of pelvic surgery. }\end{array}$
\end{tabular}

\subsection{Postpartum hysterectomy}

Consensus-based Recommendation 8.E23

Expert consensus

Level of consensus +++

Conservative measures to preserve the uterus are only useful if the patient is haemodynamically stable and does not have life-threatening bleeding $[89,90]$. The decision that hysterectomy is indicated must not be delayed or left too late.

\section{Consensus-based Recommendation 8.E24}

\section{Expert consensus}

Level of consensus +++

Supracervical hysterectomy is the procedure of choice for atony, as the operating time is significantly shorter and the operation does not lead to unintended vaginal shortening. Total hysterectomy should be considered for placental implantation disorders of the lower uterine segment; visualisation of the ureters during this procedure is recommended. 


\section{Relative contraindications for uterus-preserving measures} are:

- Extensive abnormally invasive placenta (placenta increta/ percreta) where the placental implantation bed is open, bleeding from the placental implantation bed is resistant to treatment or the implantation bed covers large areas of the uterine wall.

- Non-reconstructable uterine injury

- Septic uterus

Consensus-based Recommendation 8.E25

Expert consensus

Level of consensus ++

During the bridging time to definitive treatment, (bimanual) compression of the aorta for up to 20 minutes may be carried out to avoid unnecessary blood loss [91, 92]. If it is clear that the haemorrhage cannot be controlled by hysterectomy or is continuing even though hysterectomy has been carried out, the lesser pelvis and abdomen should be packed with sufficient moistened abdominal cloths.

\subsection{Arterial catheter embolisation}

Consensus-based Recommendation 8.E26

Expert consensus

Level of consensus +++

Every obstetric department should ascertain whether arterial catheter embolisation can be performed in their facility and the time it takes for this method to be available and then create the organisational structure which will determine at what point the patient should be transferred to the interventional radiology department. The precondition for transfer is that the patient is haemodynamically stable and does not have massive bleeding.

Consensus-based Recommendation 8.E27

Expert consensus Level of consensus ++

If catheter embolisation is available on site, the radiologist should be notified early (e.g. when an attempt at haemostasis using uterine compression sutures is unsuccessful). Because of the range of side effects, medical and surgical treatment options should be largely exhausted. The time of transfer to the radiology department is also determined by how important it is to preserve the uterus.

\section{Consensus-based Recommendation 8.E28}

Expert consensus

Level of consensus +++

Before the patient is transferred, intra-abdominal packing should be considered as a bridging procedure if the patient has just undergone a hysterectomy procedure to prevent a critical loss of blood during transportation and contain the bleeding during the sometimes protracted intervention.

\section{Consensus-based Recommendation 8.E29}

Expert consensus

Level of consensus ++

If the intervention can be planned ahead (e.g., placenta increta/percreta), endovascular catheters can already be placed preoperatively into the internal iliac artery on both sides.
Catheter embolisation may be used as a last resort to treat persistent diffuse bleeding in the lesser pelvis after postpartum hysterectomy [93].

\section{$9 \quad$ Haemostasis and Coagulation Management - Intensive Medical Procedures}

\subsection{Background}

Understanding and recognising the most probable pathophysiology of the bleeding is important, as this will offer pointers for different therapeutic approaches. The problem associated with haemostatic management is the difficulty in differentiating between increased bleeding caused by a major injury and protracted bleeding where the composition of blood has changed (i.e., the normal capacity of the system to compensate for smaller injuries has been reversed; this equates to an impairment of the coagulation system = coagulopathy). It is therefore necessary to distinguish between:

- trauma-induced coagulopathy with shock and massive tissue trauma

- initial "traumatic" haemorrhage caused by tissue trauma, and

- initial coagulopathic bleeding.

Impaired coagulation (= coagulopathy) is often an early pathology of $\mathrm{PPH}$ which can occur before dilutional coagulopathy occurs [39, 94].

Consensus-based Recommendation 9.E30

Expert consensus

Level of consensus +++

The length of time needed to obtain diagnostic findings means that it is not possible to await the results of diagnostic procedures which differentiate between different coagulopathies (e.g. congenital vs. acquired) before making treatment decisions. As a rule (if the patient's medical history does not indicate any congenital coagulopathy), it should be assumed that patients with peripartum or postpartum haemorrhage have an acquired coagulopathy, unless a surgical cause of haemorrhage can be clearly identified.

It is also important to take account of the fact that, because of the associated dilution effect and the use of coagulation factors, every primary mechanical bleeding treated with volume replacement and fresh frozen plasma (FFP) will become coagulopathic if volume substitution and FFP administration is continued over a lengthy period [95-97].

\footnotetext{
Consensus-based Statement 9.56

Expert consensus Level of consensus +++

It is therefore essential that all hospitals with obstetric departments develop a treatment algorithm for peri-/postpartum haemorrhage which is adapted to the specific conditions in the respective hospital [46, 98-101]. The aim must be to identify haemorrhaging patients early on and describe the appropriate interdisciplinary surgical, interventional and haemostatic treatment to manage the bleeding. This algorithm should define the approach for the treatment process based on the clinical situation and take account of all available treatment options (pharmacological therapies, interventional procedures, surgical interventions).
} 


\subsection{Options to treat peri-/postpartum coagulopathic haemorrhage}

\section{Consensus-based Statement 9.57}

\section{Expert consensus}

Level of consensus +++

During active bleeding, any iatrogenic aggravation of the tendency to bleed (e.g. by administering artificial colloids for volume replacement which has a strong dilution-related coagulopathic effect, or attempt to achieve high-normal blood pressure) should be avoided, where possible.

\section{Consensus-based Statement 9.58}

\section{Expert consensus}

Level of consensus ++

Blood component therapy is currently the standard therapy for haemostasis, either using labile (cellular components, FFP) or stable (lyophilised factor concentrates) blood products, and should be administered early to prevent dilutional coagulopathy occurring in addition to the already existing loss of blood.

Based on the current state of knowledge, fibrinogen plays a key role. In patients with a history of peri-/postpartum haemorrhage and patients with peripartum bleeding, plasma fibrinogen concentrations should be determined (irrespective of treatment), as concentrations $<2 \mathrm{~g} / \mathrm{l}$ could help identify those patients at increased risk of severe $\mathrm{PPH}[39,46]$.

\section{Consensus-based Recommendation 9.E31}

\section{Expert consensus}

Level of consensus ++

In any case, potentially increased fibrinolytic activity should be treated by the administration of tranexamic acid (an antifibrinolytic) before the substitution of fibrinogen (factor concentrate or FFP) is considered [39].

\section{Consensus-based Statement 9.59}

\section{Expert consensus}

Level of consensus +++

The beneficial effects (lower loss of blood, reduced blood transfusion, increased $\mathrm{Hb}$, lower number of invasive procedures) of administering tranexamic acid to treat PPH have since been shown in randomised, controlled studies of around 2000 patients [102-110].

In 2013 the ESA issued a strong recommendation based on moderate evidence for the administration of tranexamic acid to treat obstetric bleeding to reduce blood loss, bleeding duration and the number of transfusions [46].

There are no reliable data on the use of DDAVP (Minirin ${ }^{\circledR}$ ) in obstetrics which would permit an evidence-based recommendation [111], although there have been repeated reports of observational studies with positive outcomes [112]. According to the ESA, DDAVP may be useful to treat platelet function disorders resulting from acquired von Willebrand syndrome (from drugs, acidosis, hypothermia) [46].

\section{Consensus-based Recommendation 9.E32}

\section{Expert consensus}

\section{Level of consensus +++}

Although the data is controversial and prospective randomised studies are lacking, one or two attempts at treatment with rFVIla at a dose of $90 \mu \mathrm{g} / \mathrm{kg}$ BW can be undertaken as a last resort in carefully selected cases if

1. the patient has previously received adequate and appropriate treatment with other blood products,

2. the other methods used for haemostasis were not sufficiently effective, and

3. the patient still wants to have other children before undergoing a hysterectomy $[39,113-116]$.

Because of the risk of thromboembolism, recombinant FVIla (NovoSeven ${ }^{\circledR}$ ) should only be given as a last resort [117]. Plasmatic factor concentrations and platelet numbers should be optimised before rFVIIa is administered [46].

\section{Consensus-based Statement 9.510}

\section{Expert consensus} Level of consensus ++

In summary, the conclusions to be drawn from the currently available data on haemostatic management recommend

- an escalating concept (i.e., a successive step-by-step range of treatment options) adapted to the respective conditions in each hospital [46, 99, 100],

- early administration of tranexamic acid, preferably immediately after making the diagnosis,

- stabilisation of physiological preconditions for coagulation (i.e. $\mathrm{pH}$, temperature, calcium level) [46, 95],

- if bleeding persists, viscoelastic test or conventional diagnostic tests to diagnose the cause of bleeding,

- if bleeding persists and substitution is required (if need be, in parallel to other mechanical forms of treatment), early replacement of coagulation factors with factor concentrates and/or FFP (fibrinogen should be considered if dilutional coagulopathy is present, otherwise PCC and F XIII may be used),

- if necessary (i.e. when other approaches are not effective), optimisation of platelet numbers (target $>100,000 / \mu$ for patients with active bleeding requiring transfusion) [46].

\section{Consensus-based Recommendation 9.E33}

\section{Expert consensus $\quad$ Level of consensus +++}

After the underlying cause of bleeding has been treated, thromboprophylaxis must be administered within 24 hours [39]. Because of the reduced antithrombin activity (absolute activity may even be less than $0.5 \mathrm{kIU} / \mathrm{I}$ ) in the majority of women with $\mathrm{PPH}$, an increased risk of thromboembolism is expected after the bleeding has stopped [118]. After the administration of individual coagulation factor concentrates or complex preparations (e.g. PCC), antithrombin activity can be determined on the intensive care unit and substituted if necessary [119]. The target value is $\geq 80 \%$ or $\geq 0.8 \mathrm{kIU} / \mathrm{l}$ [119-121]. 
Consensus-based Recommendation $9 . \mathrm{E} 34$

\section{Expert consensus}

\section{Level of consensus +++}

- Maintain or achieve haemodynamic stability and normovolaemia: myocardiac ischaemia with reduced contractility is often present when $\mathrm{Hb}$ values $\leq 6 \mathrm{~g} / \mathrm{dl}$ (3.726 mmol/I) with or without haemodynamic abnormality $\left(R_{\text {sys }}<90 \mathrm{mmHg}\right.$ and/or $R R_{\text {dia }}<50 \mathrm{mmHg}$ and/or $\left.\mathrm{HR} \geq 115 / \mathrm{min}\right)[122,123]$.

- Timely call for expert assistance is recommended for uncontrolled blood loss of more than $500 \mathrm{ml}$ following vaginal delivery or more than $1000 \mathrm{ml}$ following Caesarean section and is essential if blood loss is more than $1500 \mathrm{ml}[29,89,95,124]$.

- For patients receiving regional anaesthesia (spinal anaesthesia, epidural anaesthesia): if blood loss is $\geq 1500-2000 \mathrm{ml}$ and there are signs of persistent bleeding: secure the airway and ensure sufficient oxygen supply; if necessary, perform early intubation after consultation with the surgeon [125]. If there is a loss of protective reflexes, endotracheal intubation to secure the airway and ensure sufficient oxygenation must take priority.

- Place wide-diameter access points ( $2 x \geq 16 \mathrm{G}$ ) followed by arterial blood pressure measurement, if necessary even before intubation. A wide-diameter central access $(\geq 9 \mathrm{Fr})$ is recommended [125-128].

- Cell saver blood (official recommendations of CMACE, NICE, OAA/AAGBI, ESA): use of mechanical autotransfusion in patients undergoing elective Caesarean section (e.g. in cases with placenta increta/percreta) can reduce the administration of allogenic blood postoperatively and the duration of hospital stay [129, 130]. In the emergency setting of PPH the following caveats must be taken into consideration: should only be used, after amniotic fluid removal and delivery of the neonate.

- Cell-saver blood does not contain clotting factors or platelets. Coagulation factors should be substituted to prevent coagulopathy when administering high transfusion volumes [131].

- Cases of hypotension have been reported following the re-transfusion of cell-saver blood with a leukocyte depletion filter [132].

- Target values in haemodynamic therapy

for "healthy" pregnant women and strong bleeding:

- After cord clamping, hypotensive resuscitation until surgical haemostasis is achieved with restrictive fluid therapy $[133,134]$.

- "Normal recapillarisation time" or "palpable radial pulse" are the target values for volume replacement therapy $[135,136]$

- Goal: MAP> $65 \mathrm{mmHg}$ or lower [137] or $\mathrm{RR}_{\text {sys }} \sim 90 \mathrm{mmHg}$ [138].

- Target Hb: indication for blood transfusion until surgical haemostasis: $7 \mathrm{~g} / \mathrm{dl}(4.347 \mathrm{mmol} / \mathrm{l})$; after surgical haemostasis and successful treatment of the underlying pathology: $7-9 \mathrm{~g} / \mathrm{dl}(4.347-5.589 \mathrm{mmol} / \mathrm{l})[23,134,138]$.

Note: ensure sufficient additional iron supplementation on the ward postoperatively.

- Pharmacological thromboprophylaxis within 24 hours after the pathology causing the bleeding has been treated [134].

Escalating regimen of haemostatic therapeutic options to treat PPH (based on recommendations of the S3-guideline 012/019 "Polytrauma/Schwerverletztenbehandlung" [Multitrauma/Treatment of Severely Injured Persons], DGAI recommendations on treating severe bleeding and ESA recommendations on treating perioperative haemorrhage) $[100,136]$.

1. Stabilise general conditions (prophylaxis and therapy!)

Core temperature $\geq 34^{\circ} \mathrm{C}$ (preferably normothermia)

$\mathrm{pH} \geq 7.2$

ionised $\mathrm{Ca}^{++}$concentration $>0.9 \mathrm{mmol} / \mathrm{I}$ (preferably normocalcaemia)

2. Prevent potential (hyper-) fibrinolysis (always PRIOR to the administration of fibrinogen and/or FFP!)

3. Substitution of oxygen carriers

4. Substitution of clotting factors (if severe haemorrhage persists) depending on availability in hospital

Tranexamic acid (Cyklokapron ${ }^{\circledR}$ ) initially 1-2 g (15-30 mg/kg BW), repeat as needed

RBC administration

Haemostatic target in patients with severe bleeding: $\mathrm{Hb} \sim 7-9 \mathrm{~g} / \mathrm{dl}$

(4.3-5.5 mmol/l) or $\mathrm{Hct} \sim 30 \%$

FFP $\geq 20$ (preferably 30 ) $\mathrm{ml} / \mathrm{kg} \mathrm{BW}$

or/and

fibrinogen (Haemocomplettan ${ }^{\circledR}$ ) (2-)4(-8) g (30-60 mg/kg BW)

Target: $\geq 200 \mathrm{mg} / \mathrm{dl}$ or $\geq 2.0 \mathrm{~g} / \mathrm{l}$

If required, PCC initially 1000-2500 IU (25 IU/kg BW)

If required, 1-2× FXIII (Fibrogammin ${ }^{\circledR}$ P)E; 1250 IU (15-20 IU/kg BW)

fusion or suffer life-threatening haemorrhagic shock may benefit

from high FFP: RBC ratio of $\geq 1: 2$ or from combined administration of FFP and factor concentrates.

and (if thrombocytopenia is suspected) increased platelet adhesion to endothelium + release of von Willebrand factor and FVIII from endothelium/liver sinusoids ( $\rightarrow$ agonist for vasopressin type 2 receptor)

5. Platelet substitution for primary haemostasis

6. If necessary, thrombin burst with platelet and coagulation activation (consider general haemostatic conditions!)

During ongoing bleeding

DDAVP $=$ desmopressin $\left(\right.$ Minirin $\left.^{\circledR}\right)$

$0.3 \mu \mathrm{g} / \mathrm{kg}$ BW over a period of 30 minutes (1 vial per $10 \mathrm{~kg}$ BW over a period of $30 \mathrm{~min}$ )

Platelet concentrate (target for haemorrhage requiring transfusion: $100000 / \mu l$ )

In individual cases and when all other treatment options have been unsuccessful

rFVIla (NovoSeven ${ }^{\circledR}$ ) if required, initially $90 \mu \mathrm{g} / \mathrm{kg}$ BW

No antithrombin (ATIII) during haemorrhage, may be considered after administration of PCC and cessation of bleeding

No heparin during haemorrhage

CAUTION: Thrombosis prophylaxis is mandatory within 24 hours after cessation of the pathology causing the bleeding! 


\subsection{Rotational thromboelastometry (ROTEM)/ thromboelastography (TEG)}

The mean time until the results of standard laboratory parameters are available in the operating room is at least 45 minutes [139]. Coagulation disturbances can be detected significantly faster with the viscoelastic test (VET) $[139,140]$.

Currently, two procedures are used for point-of-care (POC) diagnostics offering prompt, bedside recognition of clotting disorders based on VET: rotational thromboelastometry (ROTEM, Tem International $\mathrm{GmbH}$, Munich, Germany) and thromboelastography (TEG, Haemonetics, Braintree, MA, USA) [141].

At present there are no class 1 recommendations on the use of these procedures [46].

\section{Transportation}

\begin{tabular}{l} 
Consensus-based Recommendation $10 . E 35$ \\
\hline \multicolumn{1}{c|}{ Expert consensus } \\
As transporting a haemodynamically instable patient is a serious risk, any \\
transportation of such patients as part of the management of PPH must be \\
carefully weighed up, quite apart from the organisational conditions at the \\
facility caring for the patient (or transportation should only be considered \\
after haemodynamic stabilisation). It is important that the facility transfer- \\
ring the patient and the facility accepting the patient agree about timing \\
and staff coverage during transportation of the patient in the run-up to the \\
patient transfer and record what the two facilities have agreed upon in \\
writing [142].
\end{tabular}

\section{Monitoring after PPH}

\begin{tabular}{|c|c|}
\hline \multicolumn{2}{|c|}{ Consensus-based Recommendation 11.E36 } \\
\hline Expert consensus & Level of consensus +++ \\
\hline $\begin{array}{l}\text { Following PPH, individually } \\
\text { for at least } 24 \text { hours. }\end{array}$ & honitoring must be carried \\
\hline
\end{tabular}

\section{Documentation}

\section{Consensus-based Recommendation 12.E37}

Expert consensus

Level of consensus +++

Every event defined as an emergency must be carefully documented. It is recommended to use the special forms developed for the respective organisational unit for documentation.

\section{Debriefing}

\section{Consensus-based Recommendation 13.E38}

Expert consensus
Level of consensus +++

Interdisciplinary team debriefing is recommended.

\section{$14 \quad$ Training}

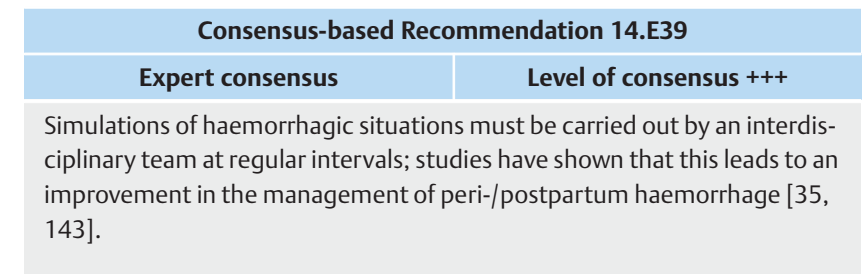

\section{Conflict of Interest}

Almost all of the authors give talks on the topic of PPH at conferences and company-sponsored meetings.

References

[1] Dupont C, Touzet S, Colin C et al. Incidence and management of postpartum haemorrhage following the dissemination of guidelines in a network of 16 maternity units in France. Int J Obstet Anesth 2009; 18: 320327

[2] Knight M, Callaghan WM, Berg C et al. Trends in postpartum hemorrhage in high resource countries: a review and recommendations from the International Postpartum Hemorrhage Collaborative Group. BMC Pregnancy Childbirth 2009; 9: 55

[3] Bateman BT, Berman MF, Riley LE et al. The epidemiology of postpartum hemorrhage in a large, nationwide sample of deliveries. Anesth Analg 2010; 110: 1368-1373

[4] Callaghan WM, Kuklina EV, Berg CJ. Trends in postpartum hemorrhage: United States, 1994-2006. Am J Obstet Gynecol 2010; 202: 353.e1353.e6

[5] Kramer MS, Berg C, Abenhaim H et al. Incidence, risk factors, and temporal trends in severe postpartum hemorrhage. Am J Obstet Gynecol 2013; 209: 449.e1-449.e7

[6] Joseph KS, Rouleau J, Kramer MS et al. Investigation of an increase in postpartum haemorrhage in Canada. BJOG 2007; 114: 751-759

[7] Samangaya R, Pennington R, Vause S. Factors relating to a rising incidence of major postpartum haemorrhage. BJOG 2010; 117: 370; author reply $370-371$

[8] Kramer MS, Dahhou M, Vallerand D et al. Risk factors for postpartum hemorrhage: can we explain the recent temporal increase? J Obstet Gynaecol Can 2011; 33: 810-819

[9] Buchanan SL, Patterson JA, Roberts CL et al. Trends and morbidity associated with oxytocin use in labour in nulliparas at term. Aust N Z J Obstet Gynaecol 2012; 52: 173-178

[10] Liu S, Joseph KS, Hutcheon JA et al. Gestational age-specific severe maternal morbidity associated with labor induction. Am J Obstet Gynecol 2013; 209: 209.e1-209.e8

[11] Mehrabadi A, Hutcheon JA, Lee L et al. Epidemiological investigation of a temporal increase in atonic postpartum haemorrhage: a populationbased retrospective cohort study. BJOG 2013; 120: 853-862

[12] Mousa HA, Walkinshaw S. Major postpartum haemorrhage. Curr Opin Obstet Gynecol 2001; 13: 595-603

[13] Waterstone M, Bewley S, Wolfe C. Incidence and predictors of severe obstetric morbidity: case-control study. BMJ 2001; 322: 1089-1093; discussion 1093-1084

[14] AbouZahr C. Global burden of maternal death and disability. Br Med Bull 2003; 67: 1-11 
[15] Hogberg U. The World Health Report 2005: "make every mother and child count” - including Africans. Scand J Public Health 2005; 33: 409411

[16] American College of Obstetricians and Gynecologists. ACOG Practice Bulletin: Clinical Management Guidelines for Obstetrician-Gynecologists Number 76, October 2006: postpartum hemorrhage. Obstet Gynecol 2006; 108: 1039-1047

[17] Khan KS, Wojdyla D, Say L et al. WHO analysis of causes of maternal death: a systematic review. Lancet 2006; 367: 1066-1074

[18] Roberts CL, Ford JB, Algert CS et al. Trends in adverse maternal outcomes during childbirth: a population-based study of severe maternal morbidity. BMC Pregnancy Childbirth 2009; 9: 7

[19] Ronsmans C, Graham W]; Lancet Maternal Survival Series steering group. Maternal mortality: who, when, where, and why. Lancet 2006; 368: $1189-1200$

[20] Cantwell R, Clutton-Brock T, Cooper G et al. Saving mothers' lives: reviewing maternal deaths to make motherhood safer: 2006-2008. The eighth report of the confidential enquiries into maternal deaths in the United Kingdom. BJOG 2011; 118 (Suppl. 1): 1-203

[21] Haeri S, Dildy GA 3rd. Maternal mortality from hemorrhage. Semin Perinatol 2012; 36: 48-55

[22] Grobman WA, Bailit JL, Rice MM et al. Frequency of and factors associated with severe maternal morbidity. Obstet Gynecol 2014; 123: 804810

[23] Arulkuman S, Mavrides E, Penney GC. RCOG Green-top Guideline No. 52: Prevention and management of postpartum haemorrhage. 2011. Online: https://www.rcog.org.uk/en/guidelines-research-services/ guidelines/gtg52/; last access: 04.04.2018

[24] Farquhar C, Sadler L, Masson V et al. Beyond the numbers: classifying contributory factors and potentially avoidable maternal deaths in New Zealand, 2006-2009. Am J Obstet Gynecol 2011; 205: 331.e1-331.e8

[25] Saucedo M, Deneux-Tharaux C, Bouvier-Colle MH; French National Experts Committee on Maternal Mortality. Ten years of confidential inquiries into maternal deaths in France, 1998-2007. Obstet Gynecol 2013; 122: $752-760$

[26] Duthie SJ, Ven D, Yung GL et al. Discrepancy between laboratory determination and visual estimation of blood loss during normal delivery. Eur J Obstet Gynecol Reprod Biol 1991; 38: 119-124

[27] Descargues G, Pitette P, Gravier A et al. [Missed diagnosis of postpartum hemorrhage]. J Gynecol Obstet Biol Reprod (Paris) 2001; 30: 590-600

[28] Bose P, Regan F, Paterson-Brown S. Improving the accuracy of estimated blood loss at obstetric haemorrhage using clinical reconstructions. BJOC 2006; 113: 919-924

[29] Rath W, Schneider M. Definitionen und Diagnostik postpartaler Blutungen (PPH): Unterschätzte Probleme! [Definitions and Diagnosis of Postpartum Haemorrhage (PPH): Underestimated Problems!]. Geburtsh Frauenheilk 2010; 70: 36-40

[30] Alexander J, Thomas P, Sanghera J. Treatments for secondary postpartum haemorrhage. Cochrane Database Syst Rev 2002; (1): CD002867

[31] Rizvi F, Mackey R, Barrett T et al. Successful reduction of massive postpartum haemorrhage by use of guidelines and staff education. BJOG 2004; 111: 495-498

[32] Obstetrical hemorrhage. In: Cunningham FG, Leveno KJ, Bloom SL, Hauth JC, Rouse DJ, Spong CY, eds. Williams Obstetrics. 23rd ed. New York: McGraw-Hill; 2010: 757-803

[33] Upadhyay K, Scholefield H. Risk management and medicolegal issues related to postpartum haemorrhage. Best Pract Res Clin Obstet Gynaecol 2008; 22: 1149-1169

[34] Driessen M, Bouvier-Colle MH, Dupont C et al. Postpartum hemorrhage resulting from uterine atony after vaginal delivery: factors associated with severity. Obstet Gynecol 2011; 117: 21-31
[35] Main EK, Goffman D, Scavone BM et al. National partnership for maternal safety: consensus bundle on obstetric hemorrhage. Obstet Gynecol 2015; 126: 155-162

[36] Merz E, Eichhorn KH, von Kaisenberg C et al.; Arbeitsgruppe der DEGUMStufe III. [Updated quality requirements regarding secondary differentiated ultrasound examination in prenatal diagnostics (= DEGUM level II) in the period from $18+0$ to $21+6$ weeks of gestation]. Ultraschall Med 2012; 33: 593-596

[37] Al-Zirqi I, Vangen S, Forsen L et al. Prevalence and risk factors of severe obstetric haemorrhage. BJOG 2008; 115: 1265-1272

[38] Sosa CG, Althabe F, Belizan JM et al. Risk factors for postpartum hemorrhage in vaginal deliveries in a Latin-American population. Obstet Gynecol 2009; 113: 1313-1319

[39] Abdul-Kadir R, McLintock C, Ducloy AS et al. Evaluation and management of postpartum hemorrhage: consensus from an international expert panel. Transfusion 2014; 54: 1756-1768

[40] Rajan PV, Wing DA. Postpartum hemorrhage: evidence-based medical interventions for prevention and treatment. Clin Obstet Gynecol 2010; 53: $165-181$

[41] Comstock CH. Antenatal diagnosis of placenta accreta: a review. Ultrasound Obstet Gynecol 2005; 26: 89-96

[42] Comstock CH, Bronsteen RA. The antenatal diagnosis of placenta accreta. BJOG 2014; 121: 171-181; discussion 181-172

[43] Chalubinski KM, Pils S, Klein K et al. Prenatal sonography can predict degree of placental invasion. Ultrasound Obstet Gynecol 2013; 42: 518524

[44] Kluckow M, Hooper SB. Using physiology to guide time to cord clamping. Semin Fetal Neonatal Med 2015; 20: 225-231

[45] Rath W, Bohlmann MK. Postpartale Hämorrhagie - Prävention und Therapie. Gynäkologe 2011; 44: 538-548

[46] Kozek-Langenecker SA, Afshari A, Albaladejo P et al. Management of severe perioperative bleeding: guidelines from the European Society of Anaesthesiology. Eur J Anaesthesiol 2013; 30: 270-382

[47] von Heymann C, Kaufner L, Korber M. [Perioperative management and therapy of bleeding complications]. Anasthesiol Intensivmed Notfallmed Schmerzther 2014; 49: 196-204; quiz 205

[48] Montufar-Rueda C, Rodriguez L, Jarquin JD et al. Severe postpartum hemorrhage from uterine atony: a multicentric study. J Pregnancy 2013; 2013: 525914

[49] Rath W. [Postpartum Haemorrhage (PPH): "too little is done too late"!] Z Geburtshilfe Neonatol 2011; 215: 177-181

[50] Teixidor Vinas M, Chandraharan E, Moneta MV et al. The role of interventional radiology in reducing haemorrhage and hysterectomy following caesarean section for morbidly adherent placenta. Clin Radiol 2014; 69: e345-e351

[51] Teixidor Vinas M, Belli AM, Arulkumaran S et al. Prevention of postpartum hemorrhage and hysterectomy in patients with morbidly adherent placenta: a cohort study comparing outcomes before and after introduction of the Triple-P procedure. Ultrasound Obstet Gynecol 2015; 46: 350-355

[52] Fuchs I, Dudenhausen JW, Sehouli ] et al. Placenta pathology: disorders of placental location, placental implantation and cord insertion. Ultraschall Med 2008; 29: 4-17; quiz 18-23

[53] You WB, Zahn CM. Postpartum hemorrhage: abnormally adherent placenta, uterine inversion, and puerperal hematomas. Clin Obstet Gynecol 2006; 49: 184-197

[54] Witteveen T, van Stralen G, Zwart J et al. Puerperal uterine inversion in the Netherlands: a nationwide cohort study. Acta Obstet Gynecol Scand 2013; 92: 334-337

[55] Kenyon S, Tokumasu H, Dowswell T et al. High-dose versus low-dose oxytocin for augmentation of delayed labour. Cochrane Database Syst Rev 2013; (7): CD007201 
[56] Langer B, Boudier E, Haberstich R et al.; Collège National des Gynécologues et Obstétriciens Français; Agence Nationale d'Accréditation et d'Evaluation en Santé. [Obstetrical management in the event of persistent or worsening postpartum hemorrhage despite initial measures]. J Gynecol Obstet Biol Reprod (Paris) 2004; 33 (8 Suppl.): 4S73-4S79

[57] Surbek DV, Fehr PM, Hosli I et al. Oral misoprostol for third stage of labor: a randomized placebo-controlled trial. Obstet Gynecol 1999; 94 : $255-258$

[58] Hofmeyr G], Walraven G, Gulmezoglu AM et al. Misoprostol to treat postpartum haemorrhage: a systematic review. BJOG 2005; 112: 547553

[59] Langenbach C. Misoprostol in preventing postpartum hemorrhage: a meta-analysis. Int J Gynaecol Obstet 2006; 92: 10-18

[60] Lapaire O, Schneider MC, Stotz M et al. Oral misoprostol vs. intravenous oxytocin in reducing blood loss after emergency cesarean delivery. Int J Gynaecol Obstet 2006; 95: 2-7

[61] Mousa HA, Blum J, Abou El Senoun G et al. Treatment for primary postpartum haemorrhage. Cochrane Database Syst Rev 2014; (2): CD003249

[62] Schlembach D, Moertl MG, Girard T et al. Management der postpartalen Blutung. Der D-A-CH-Algorithmus. Frauenarzt 2013; 54: 1072-1080

[63] Kaufner L, Schuster M, Vogt M et al. [Case report: recurrent postpartum haemorrhage after emergency caesarean section - clipping, embolization and haemostaseological therapy]. Anasthesiol Intensivmed Notfallmed Schmerzther 2012; 47: 308-314

[64] Gronvall M, Tikkanen M, Tallberg E et al. Use of Bakri balloon tamponade in the treatment of postpartum hemorrhage: a series of 50 cases from a tertiary teaching hospital. Acta Obstet Gynecol Scand 2013; 92: 433438

[65] Chan LL, Lo TK, Lau WL et al. Use of second-line therapies for management of massive primary postpartum hemorrhage. Int J Gynaecol Obstet 2013; 122: 238-243

[66] Ibrahim M, Ziegler C, Klam SL et al. Incidence, indications, and predictors of adverse outcomes of postpartum hysterectomies: 20-year experience in a tertiary care centre. J Obstet Gynaecol Can 2014; 36: 14-20

[67] Dabelea V, Schultze PM, McDuffie RS jr. Intrauterine balloon tamponade in the management of postpartum hemorrhage. Am J Perinatol 2007; 24: $359-364$

[68] Patacchiola F, D’Alfonso A, Di Fonso A et al. Intrauterine balloon tamponade as management of postpartum haemorrhage and prevention of haemorrhage related to low-lying placenta. Clin Exp Obstet Gynecol 2012; 39: 498-499

[69] Aibar L, Aguilar MT, Puertas A et al. Bakri balloon for the management of postpartum hemorrhage. Acta Obstet Gynecol Scand 2013; 92: 465467

[70] Florian A, Carles G, Dallah F et al. [Value of the Linton-Nachlas balloon for the management of post-partum hemorrhage: a series of 25 cases]. J Gynecol Obstet Biol Reprod (Paris) 2013; 42: 493-498

[71] Nelson BD, Stoklosa H, Ahn R et al. Use of uterine balloon tamponade for control of postpartum hemorrhage by community-based health providers in South Sudan. Int J Gynaecol Obstet 2013; 122: 27-32

[72] Tindell K, Garfinkel R, Abu-Haydar E et al. Uterine balloon tamponade for the treatment of postpartum haemorrhage in resource-poor settings: a systematic review. BJOG 2013; 120: 5-14

[73] Morel O, Perdriolle-Galet E, Mezan de Malartic C et al. [Management of severe or persistent postpartum hemorrhage after vaginal delivery.]. J Gynecol Obstet Biol Reprod (Paris) 2014; 43: 1019-1029

[74] Schmid BC, Rezniczek GA, Rolf N et al. Uterine packing with chitosancovered gauze for control of postpartum hemorrhage. Am J Obstet Gynecol 2013; 209: 225.e1-225.e5
[75] Diemert A, Ortmeyer G, Hollwitz B et al. The combination of intrauterine balloon tamponade and the B-Lynch procedure for the treatment of severe postpartum hemorrhage. Am J Obstet Gynecol 2012; 206: 65.e165.e4

[76] Nelson WL, O'Brien JM. The uterine sandwich for persistent uterine atony: combining the B-Lynch compression suture and an intrauterine Bakri balloon. Am J Obstet Gynecol 2007; 196: e9-e10

[77] Merrick K, Jibodu OA, Rajesh U. The difficult PPH: experience of combined use of B-Lynch brace suture and intrauterine Bakri balloon in York hospital, UK. J Obstet Gynaecol 2013; 33: 314-315

[78] Cekmez Y, Ozkaya E, Ocal FD et al. Experience with different techniques for the management of postpartum hemorrhage due to uterine atony: compression sutures, artery ligation and Bakri balloon. Ir J Med Sci 2015; 184: 399-402

[79] Deux JF, Bazot M, Le Blanche AF et al. Is selective embolization of uterine arteries a safe alternative to hysterectomy in patients with postpartum hemorrhage? AJR Am J Roentgenol 2001; 177: 145-149

[80] Rath W, Hackethal A, Bohlmann MK. Second-line treatment of postpartum haemorrhage (PPH). Arch Gynecol Obstet 2012; 286: 549-561

[81] Sentilhes L, Gromez A, Razzouk K et al. B-Lynch suture for massive persistent postpartum hemorrhage following stepwise uterine devascularization. Acta Obstet Gynecol Scand 2008; 87: 1020-1026

[82] Sentilhes L, Trichot C, Resch B et al. Fertility and pregnancy outcomes following uterine devascularization for severe postpartum haemorrhage. Hum Reprod 2008; 23: 1087-1092

[83] Gaia G, Chabrot P, Cassagnes L et al. Menses recovery and fertility after artery embolization for PPH: a single-center retrospective observational study. Eur Radiol 2009; 19: 481-487

[84] Sentilhes L, Gromez A, Trichot C et al. Fertility after B-Lynch suture and stepwise uterine devascularization. Fertil Steril 2009; 91: 934.e5-934.e9

[85] Hollatz-Galuscki E, Michaelis S, Rauber S et al. Uteruskompressionsnähte - Welche Nahttechnik ist wann indiziert? Geburtsh Frauenheilk 2013; 73: P70

[86] O'Leary JA. Uterine artery ligation in the control of postcesarean hemorrhage. J Reprod Med 1995; 40: 189-193

[87] AbdRabbo SA. Stepwise uterine devascularization: a novel technique for management of uncontrolled postpartum hemorrhage with preservation of the uterus. Am J Obstet Gynecol 1994; 171: 694-700

[88] Morel O, Malartic C, Muhlstein J et al. Pelvic arterial ligations for severe post-partum hemorrhage. Indications and techniques. J Visc Surg 2011; 148: e95-e102

[89] Ahonen J, Stefanovic V, Lassila R. Management of post-partum haemorrhage. Acta Anaesthesiol Scand 2010; 54: 1164-1178

[90] Rossi AC, Lee RH, Chmait RH. Emergency postpartum hysterectomy for uncontrolled postpartum bleeding: a systematic review. Obstet Gynecol 2010; 115: 637-644

[91] Riley DP, Burgess RW. External abdominal aortic compression: a study of a resuscitation manoeuvre for postpartum haemorrhage. Anaesth Intensive Care 1994; 22: 571-575

[92] Keogh J, Tsokos N. Aortic compression in massive postpartum haemorrhage-an old but lifesaving technique. Aust N Z J Obstet Gynaecol 1997; 37: $237-238$

[93] Bloom Al, Verstandig A, Gielchinsky Y et al. Arterial embolisation for persistent primary postpartum haemorrhage: before or after hysterectomy? BJOG 2004; 111: 880-884

[94] McLintock C, James AH. Obstetric hemorrhage. J Thromb Haemost 2011; 9: 1441-1451

[95] Lier H, Rath W. Aktuelle interdisziplinäre Handlungsempfehlungen bei schweren peri-(post-)partalen Blutungen (PPH). [Current Interdisciplinary Recommendations for the Management of Severe Postpartum Hemorrhage (PPH)]. Geburtsh Frauenheilk 2011; 71: 577-588 
[96] Schols SE, Feijge MA, Lance MD et al. Effects of plasma dilution on tissuefactor-induced thrombin generation and thromboelastography: partly compensating role of platelets. Transfusion 2008; 48: 2384-2394

[97] Tanaka KA, Key NS, Levy JH. Blood coagulation: hemostasis and thrombin regulation. Anesth Analg 2009; 108: 1433-1446

[98] Shields LE, Smalarz K, Reffigee L et al. Comprehensive maternal hemorrhage protocols improve patient safety and reduce utilization of blood products. Am J Obstet Gynecol 2011; 205: 368.e1-368.e8

[99] Mellin-Olsen J, Staender S, Whitaker DK et al. The Helsinki declaration on patient safety in anaesthesiology. Eur J Anaesthesiol 2010; 27: 592-597

[100] Grottke O, Frietsch T, Maas M et al. Umgang mit Massivblutungen und assoziierten perioperativen Gerinnungsstörungen. [Dealing with massive bleeding and associated perioperative coagulopathy: recommendations for action of the German Society of Anaesthesiology and Intensive Care Medicine]. Anaesthesist 2013; 62: 213-224

[101] Einerson BD, Miller ES, Grobman WA. Does a postpartum hemorrhage patient safety program result in sustained changes in management and outcomes? Am J Obstet Gynecol 2015; 212: 140-4.e1

[102] Yang $\mathrm{H}$, Zheng S, Shi C. [Clinical study on the efficacy of tranexamic acid in reducing postpartum blood lose: a randomized, comparative, multicenter trial]. Zhonghua Fu Chan Ke Za Zhi 2001; 36: 590-592

[103] Gai MY, Wu LF, Su QF et al. Clinical observation of blood loss reduced by tranexamic acid during and after caesarian section: a multi-center, randomized trial. Eur J Obstet Gynecol Reprod Biol 2004; 112: 154157

[104] Gohel M, Patel P, Gupta A et al. Efficacy of tranexamic acid in decreasing blood loss during and after cesarean section: a randomized case controlled prospective study. J Obstet Gynecol India 2007; 57: $227-$ 230

[105] Sekhavat L, Tabatabaii A, Dalili M et al. Efficacy of tranexamic acid in reducing blood loss after cesarean section. J Matern Fetal Neonatal Med 2009; 22: 72-75

[106] Ducloy-Bouthors AS, Jude B, Duhamel A et al. High-dose tranexamic acid reduces blood loss in postpartum haemorrhage. Crit Care 2011; 15: R117

[107] Gungorduk K, Yildirim G, Asicioglu O et al. Efficacy of intravenous tranexamic acid in reducing blood loss after elective cesarean section: a prospective, randomized, double-blind, placebo-controlled study. Am J Perinatol 2011; 28: 233-240

[108] Movafegh A, Eslamian L, Dorabadi A. Effect of intravenous tranexamic acid administration on blood loss during and after cesarean delivery. Int J Gynaecol Obstet 2011; 115: 224-226

[109] Senturk MB, Cakmak Y, Yildiz G et al. Tranexamic acid for cesarean section: a double-blind, placebo-controlled, randomized clinical trial. Arch Gynecol Obstet 2013; 287: 641-645

[110] Novikova N, Hofmeyr G], Cluver C. Tranexamic acid for preventing postpartum haemorrhage. Cochrane Database Syst Rev 2015; (6): CD007872

[111] Karanth L, Barua A, Kanagasabai S et al. Desmopressin acetate (DDAVP) for preventing and treating acute bleeds during pregnancy in women with congenital bleeding disorders. Cochrane Database Syst Rev 2013; (4): CD009824

[112] Trigg DE, Stergiotou I, Peitsidis P et al. A systematic review: the use of desmopressin for treatment and prophylaxis of bleeding disorders in pregnancy. Haemophilia 2012; 18: 25-33

[113] Ahonen J. The role of recombinant activated factor VII in obstetric hemorrhage. Curr Opin Anaesthesiol 2012; 25: 309-314

[114] Gawron LM, Goldman KN, Kiley J. A gravid development: should the desire to maintain fertility determine treatment for profuse bleeding in pregnancy? Am J Obstet Gynecol 2013; 208: 332.e1-332.e2
[115] Jan JY, Lin SY, Lin CH et al. Recombinant activated factor VII as a promising adjuvant therapy for postpartum hemorrhage in the practice of obstetric anesthesia: experience from a university hospital in Taiwan. J Obstet Gynaecol Res 2011; 37: 901-907

[116] Mercier FJ, Bonnet MP. Use of clotting factors and other prohemostatic drugs for obstetric hemorrhage. Curr Opin Anaesthesiol 2010; 23: 310-316

[117] Lavigne-Lissalde G, Aya AG, Mercier FJ et al. Recombinant human FVIla for reducing the need for invasive second-line therapies in severe refractory postpartum hemorrhage: a multicenter, randomized, open controlled trial. J Thromb Haemost 2015; 13: 520-529

[118] Kevane B, Donnelly J, D’Alton M et al. Risk factors for pregnancy-associated venous thromboembolism: a review. J Perinat Med 2014; 42 : 417-425

[119] Karlsson O, Sporrong T, Hillarp A et al. Prospective longitudinal study of thromboelastography and standard hemostatic laboratory tests in healthy women during normal pregnancy. Anesth Analg 2012; 115: 890-898

[120] Szecsi PB, Jorgensen M, Klajnbard A et al. Haemostatic reference intervals in pregnancy. Thromb Haemost 2010; 103: 718-727

[121] James AH, Konkle BA, Bauer KA. Prevention and treatment of venous thromboembolism in pregnancy in patients with hereditary antithrombin deficiency. Int J Womens Health 2013; 5: 233-241

[122] Karpati PC, Rossignol M, Pirot $M$ et al. High incidence of myocardial ischemia during postpartum hemorrhage. Anesthesiology 2004; 100 : 30-36; discussion 35A

[123] Heyer L, Mebazaa A, Gayat E et al. Cardiac troponin and skeletal muscle oxygenation in severe post-partum haemorrhage. Crit Care 2009; 13 (Suppl. 5): S8

[124] Rossen J, Okland I, Nilsen OB et al. Is there an increase of postpartum hemorrhage, and is severe hemorrhage associated with more frequent use of obstetric interventions? Acta Obstet Gynecol Scand 2010; 89: 1248-1255

[125] Gallos G, Redai I, Smiley RM. The role of the anesthesiologist in management of obstetric hemorrhage. Semin Perinatol 2009; 33: 116-123

[126] Kuczkowski KM. Anesthesia for the repeat cesarean section in the parturient with abnormal placentation: what does an obstetrician need to know? Arch Gynecol Obstet 2006; 273: 319-321

[127] Fuller AJ, Bucklin BA. Blood product replacement for postpartum hemorrhage. Clin Obstet Gynecol 2010; 53: 196-208

[128] Bonnet MP, Deneux-Tharaux C, Bouvier-Colle MH. Critical care and transfusion management in maternal deaths from postpartum haemorrhage. Eur J Obstet Gynecol Reprod Biol 2011; 158: 183-188

[129] Rainaldi MP, Tazzari PL, Scagliarini G et al. Blood salvage during caesarean section. $\mathrm{Br}$ ] Anaesth 1998; 80: 195-198

[130] Goucher H, Wong CA, Patel SK et al. Cell salvage in obstetrics. Anesth Analg 2015; 121: 465-468

[131] Catling S, Haynes SL. Coagulopathy during intraoperative cell salvage in a patient with major obstetric haemorrhage. $\mathrm{Br}$ J Anaesth 2011; 106: 749; author reply 750

[132] Waldron S. Hypotension associated with leucocyte depletion filters following cell salvage in obstetrics. Anaesthesia 2011; 66: 133-134

[133] Pacheco LD, Saade GR, Gei AF et al. Cutting-edge advances in the medical management of obstetrical hemorrhage. Am J Obstet Gyneco 2011; 205: 526-532

[134] Spahn DR, Bouillon B, Cerny V et al. Management of bleeding and coagulopathy following major trauma: an updated European guideline. Crit Care 2013; 17: R76

[135] Cotton BA, Jerome R, Collier BR et al. Guidelines for prehospital fluid resuscitation in the injured patient. J Trauma 2009; 67: 389-402 
[136] Stürmer KM, Neugebauer E, Waydhas C et al. S3-Leitlinie Polytrauma/ Schwerverletzten-Behandlung. AWMF 012/019 - S3-Leitlinie. 2011. Online: https://www.dggg.de/fileadmin/documents/leitlinien/ archiviert/federfuehrend/012019_Polytrauma_und_SchwerverletztenBehandlung/012019_2011.pdf; last access: 04.04.2018

[137] Morrison CA, Carrick MM, Norman MA et al. Hypotensive resuscitation strategy reduces transfusion requirements and severe postoperative coagulopathy in trauma patients with hemorrhagic shock: preliminary results of a randomized controlled trial. J Trauma 2011; 70: 652-663

[138] Napolitano LM, Kurek S, Luchette FA et al. Clinical practice guideline: red blood cell transfusion in adult trauma and critical care. J Trauma 2009; 67: 1439-1442

[139] de Lange NM, van Rheenen-Flach LE, Lance MD et al. Peri-partum reference ranges for ROTEM(R) thromboelastometry. $\mathrm{Br}$ J Anaesth 2014; 112: 852-859
[140] Karlsson O, Jeppsson A, Hellgren M. Major obstetric haemorrhage: monitoring with thromboelastography, laboratory analyses or both? Int J Obstet Anesth 2014; 23: 10-17

[141] McNamara H, Mallaiah S, Barclay P et al. Coagulopathy and placental abruption: changing management with ROTEM-guided fibrinogen concentrate therapy. Int J Obstet Anesth 2015; 24: 174-179

[142] Wilson AK, Martel MJ, Arsenault MY et al. Maternal transport policy. J Obstet Gynaecol Can 2005; 27: 956-963

[143] Quinn KH, Mackey A, Cohen J et al. A curriculum to teach and evaluate resident skills in the management of postpartum hemorrhage. J Perinat Med 2012; 40: 635-639 


\section{Guideline Program}

\section{Editors}

Leading Professional Medical Associations

\section{Ty}

German Society of Gynecology and Obstetrics (Deutsche Gesellschaft für Gynäkologie und Geburtshilfe e. V. [DGGG])

Head Office of DGGG and Professional Societies Hausvogteiplatz 12, DE-10117 Berlin info@dggg.de

http://www.dggg.de/

\section{President of DGGG}

Prof. Dr. Birgit Seelbach-Göbel

Universität Regensburg

Klinik für Geburtshilfe und Frauenheilkunde

St. Hedwig-Krankenhaus Barmherzige Brüder

Steinmetzstraße 1-3, DE-93049 Regensburg

\section{DGGG Guidelines Representatives}

Prof. Dr. med. Matthias W. Beckmann Universitätsklinikum Erlangen, Frauenklinik Universitätsstraße 21-23, DE-91054 Erlangen

Prof. Dr. med. Erich-Franz Solomayer Universitätsklinikum des Saarlandes Geburtshilfe und Reproduktionsmedizin Kirrberger Straße, Gebäude 9, DE-66421 Homburg

\section{Guidelines Coordination}

Dr. med. Paul Gaß, Christina Fuchs, Marion Gebhardt Universitätsklinikum Erlangen, Frauenklinik Universitätsstraße 21-23, DE-91054 Erlangen fk-dggg-leitlinien@uk-erlangen.de http://www.dggg.de/leitlinienstellungnahmen

\section{OEGGG}

Austrian Society of Gynecology and Obstetrics (Österreichische Gesellschaft für Gynäkologie und Geburtshilfe [OEGGG]) Innrain 66A, AT-6020 Innsbruck stephanie.leutgeb@oeggg.at http://www.oeggg.at

\section{President of OEGGG}

Prof. Dr. med. Petra Kohlberger

Universitätsklinik für Frauenheilkunde Wien

Währinger Gürtel 18-20, AT-1180 Wien

\section{OEGGG Guidelines Representatives}

Prof. Dr. med. Karl Tamussino

Universitätsklinik für Frauenheilkunde und Geburtshilfe Graz Auenbruggerplatz 14, AT-8036 Graz

Prof. Dr. med. Hanns Helmer Universitätsklinik für Frauenheilkunde Wien Währinger Gürtel 18-20, AT-1090 Wien

\section{gynécologie suisse}

Swiss Society of Gynecology and Obstetrics (Schweizerische Gesellschaft für Gynäkologie und Geburtshilfe [SGGG])

Gynécologie Suisse SGGG Altenbergstraße 29, Postfach 6, CH-3000 Bern 8 sekretariat@sggg.ch http://www.sggg.ch/

\section{President of SGGG}

Dr. med. David Ehm

FMH für Geburtshilfe und Gynäkologie

Nägeligasse 13, CH-3011 Bern

\section{SGGG Guidelines Representatives}

Prof. Dr. med. Daniel Surbek Universitätsklinik für Frauenheilkunde Geburtshilfe und feto-maternale Medizin Inselspital Bern Effingerstraße 102, CH-3010 Bern

Prof. Dr. med. René Hornung Kantonsspital St. Gallen, Frauenklinik Rorschacher Straße 95, CH-9007 St. Gallen 